\title{
Effects of Zinc Precursor, Basicity and Temperature on the Aqueous Synthesis of ZnO Nanocrystals
}

\author{
Maroua Mrad, Bilel Chouchene and Tahar Ben Chaabane* (i) \\ Unité de Recherche Synthèse et Structure de Nanomatériaux UR 11 ES 30. Faculté des Sciences de Bizerte, 7021 Jarzouna, \\ Bizerte. Université de Carthage, Tunisia.
}

Received 8 November 2017, revised 13 June 2018, accepted 24 July 2018

\begin{abstract}
The effects of the zinc salt precursors, the reaction temperature and the alkaline ratio $b\left(b=[\mathrm{OH}-] /\left[\mathrm{Zn}^{2+}\right]\right)$ on the aqueous synthesis of $\mathrm{ZnO}$ nanocrystals were investigated. Depending on the type of the zinc precursor, $\mathrm{Zn}_{5}(\mathrm{OH})_{8} \mathrm{Cl}_{2} \cdot \mathrm{H}_{2} \mathrm{O}$ or $\mathrm{Zn}_{5}(\mathrm{OH})_{8}\left(\mathrm{NO}_{3}\right)_{2} \cdot 2 \mathrm{H}_{2} \mathrm{O}$ lamellar phases were obtained at room temperature $\left(20^{\circ} \mathrm{C}\right)$ when the alkaline ratio is lower $(0.5 \leq \mathrm{b} \leq 1$, $6 \leq \mathrm{pH} \leq 6.4)$. When the reaction temperature increased to $95^{\circ} \mathrm{C}$, zinc hydroxide chloride monohydrate was obtained in one case whereas zinc oxide was formed in the other, and no lamellar phase of $\mathrm{Zn}_{5}(\mathrm{OH})_{8}\left(\mathrm{NO}_{3}\right)_{2} \cdot 2 \mathrm{H}_{2} \mathrm{O}$ was obtained. Thermal decomposition of the two lamellar phases was carried out and mainly showed that $\mathrm{Zn}_{5}(\mathrm{OH})_{8}\left(\mathrm{NO}_{3}\right)_{2} \cdot 2 \mathrm{H}_{2} \mathrm{O}$ was completely decomposed to $\mathrm{ZnO}$ when the annealed temperature reached $\sim 250{ }^{\circ} \mathrm{C}$ while $\mathrm{Zn}_{5}(\mathrm{OH})_{8} \mathrm{Cl}_{2} \cdot \mathrm{H}_{2} \mathrm{O}$ was totally transformed to $\mathrm{ZnO}$ at about $400{ }^{\circ} \mathrm{C}$, a higher comparative temperature that confirms the better thermal stability of the zinc hydroxide chloride monohydrate.
\end{abstract}

KEYWORDS

Oxides, $\mathrm{ZnO}$, chemical synthesis, X-ray diffraction, crystal structure, luminescence.

\section{Introduction}

Among the various II-VI semiconductors such as ZnS, ZnSe, $\mathrm{CdTe}, \mathrm{CdS}$, etc., zinc oxide $(\mathrm{ZnO})$ plays an important role in terms of chemical and physical properties. $\mathrm{ZnO}$ possesses remarkable characteristics, e.g. it is a wide bandgap semiconductor $(3.37 \mathrm{eV})$ with a large excitonic binding energy of $60 \mathrm{meV}$. Nanostructured $\mathrm{ZnO}$ remains an attractive material because it has great potential for a variety of practical applications, such as in nanoscale devices, as light-emitting diodes, ${ }^{1,2}$ magneto-optical devices, ${ }^{3}$ ultraviolet lasers, ${ }^{4,5}$ gas sensors, ${ }^{6,7}$ solar cells, ${ }^{8,9}$ photocatalysis, etc. ${ }^{10,11} \mathrm{ZnO}$ nanocrystals can be obtained in numerous morphological varieties related to a multitude of synthesis approaches. Particularly, various soft chemistry synthesis techniques have been developed to elaborate $\mathrm{ZnO}$ nanocrystals with good crystallinity and controllable shape and size, such as hydrothermal or solvothermal process, ${ }^{12,13}$ sol-gel, ${ }^{14}$ precipitation method, ${ }^{15,16}$ polyol process, etc. ${ }^{17,18}$

In this work, we have adopted the cost competitive and simple aqueous precipitation process using low-cost precursors such as zinc nitrate or zinc chloride together with sodium or potassium hydroxide to prepare zinc oxide. Our main purpose is to evaluate the influence of the zinc precursors, the basicity and the temperature on the aqueous synthesis of $\mathrm{ZnO}$. We demonstrate the important role of the alkaline ratio $b\left(b=\left[\mathrm{OH}^{-}\right] /\left[\mathrm{Zn}^{2+}\right]\right)$ and the temperature on the $\mathrm{ZnO}$ wurtzite phase formation.

As far as we know, systematic investigations of the basicity, in this case medium basicity, and the temperature effects on the $\mathrm{ZnO}$ synthesis, especially for the lower alkaline ratios ( $b \leq 2)$, has rarely been studied. For instance, A.M. Pourrahimi et al. have prepared $\mathrm{ZnO}$ nanoparticles in aqueous media, from different zinc salts and sodium hydroxide, under identical conditions with a fixed alkaline ratio $(b=2.5)^{19}$. The $\mathrm{NaOH}$ solution $(0.5 \mathrm{M})$ was heated to $60^{\circ} \mathrm{C}$ and added to the zinc metal salt solution $(0.2 \mathrm{M})$ based on nitrate, chloride, sulfate or acetate. The mixture was stirred and maintained at $60{ }^{\circ} \mathrm{C}$ for $1 \mathrm{~h}$. The recuperated powders were characterized as wurtzite zinc oxide in all cases; nevertheless, the resulting nanocrystals were obtained with

* To whom correspondence should be addressed. E-mail: taharbch@yahoo.com different morphologies that depended on the counterion type of the zinc salt. ${ }^{19}$

R.A. McBride et al. have studied the role of the zinc precursor and the temperature on the microcrystalline morphology of $\mathrm{ZnO}{ }^{20}$ They prepared zinc oxide using an aqueous solution of zinc salt $(0.04 \mathrm{M})$ and sodium hydroxide with a relatively higher alkaline ratio: $\left[\mathrm{OH}^{-}\right] /\left[\mathrm{Zn}^{2+}\right]=15$. The authors have used two general preparative procedures; the first involves simply heating the aqueous solution to $101{ }^{\circ} \mathrm{C}$ for $8 \mathrm{~h}$ which then led to the formation of star-like microcrystals of the wurtzite phase. In the second method, the same reagents were stirred at room temperature for $2 \mathrm{~h}$ to form wulfingite $\varepsilon-\mathrm{Zn}(\mathrm{OH})_{2}$ as an intermediate phase. When the mixture was heated to $101{ }^{\circ} \mathrm{C}$ for $24 \mathrm{~h}$, $\varepsilon-\mathrm{Zn}(\mathrm{OH})_{2}$ transformed to $\mathrm{ZnO}$ nanocrystals with needle shape.

$\mathrm{L}$. Jiang et al. have reported the synthesis of $\mathrm{ZnO}$ crystals under hydrothermal conditions at $180^{\circ} \mathrm{C}$ using zinc nitrate and sodium hydroxide with a high alkaline ratio of 20,30 and $80 .{ }^{21}$ All the as-synthesized products were formed with the wurtzite zinc oxide phase exhibiting flower-like morphology with sizes of 5-8 $\mu \mathrm{m}$ when the alkaline ratio was adjusted to 20 . Increasing the alkaline ratio to $b=30$, the same crystals morphology was obtained but with larger sizes of 10-20 $\mu \mathrm{m}$.

It is interesting to note that increasing attention is being paid to the solution growth of $\mathrm{ZnO}$ nanostructures to obtain different morphologies. ${ }^{22-24}$ Zinc oxide crystal formation involves the two processes of nucleation and growth. It is established that nucleation frequency and growth rate direct the shape and the size of $\mathrm{ZnO}$ crystals. The formation mechanism of the synthesized zinc oxide nanostructures in solution has been proposed and discussed by many groups. ${ }^{25,28}$ Generally, the suggested mechanism is based on the formation of wulfingite $\varepsilon-\mathrm{Zn}(\mathrm{OH})_{2}$ intermediate phase that transforms to $\mathrm{ZnO}$ wurtzite phase. Three mechanisms have been proposed:

(1) Formation of $\mathrm{ZnO}$ from $\varepsilon-\mathrm{Zn}(\mathrm{OH})_{2}$ by dissolution and reprecipitation.

(2) In situ crystallization of $\mathrm{ZnO}$ from $\mathrm{Zn}(\mathrm{OH})_{2}$ by dehydration and internal atomic arrangement. 
(3) Direct solid-solid phase transformation which occurs in the $\mathrm{Zn}(\mathrm{OH})_{2}$ matrix. ${ }^{29}$

In this paper, we mainly studied the effect of the alkaline ratio $b$ varying it in the range $0.5-4$, as well as the zinc salt precursor and the reaction temperature on the formation of the $\mathrm{ZnO}$ wurtzite phase and/or of intermediate phases. We noted that no $\varepsilon-\mathrm{Zn}(\mathrm{OH})_{2}$ was formed as an intermediate species under our experimental conditions. Possible reaction processes of the formation of $\mathrm{ZnO}$ or of the intermediate phases are proposed and discussed.

\section{Experimental}

\subsection{Synthesis}

Zinc nitrate hexahydrate $\left(\mathrm{Zn}\left(\mathrm{NO}_{3}\right)_{2} \cdot 6 \mathrm{H}_{2} \mathrm{O}\right.$ from SigmaAldrich, $98 \%$ purity), zinc chloride ( $\mathrm{ZnCl} 2$ from Fluka, 98\% purity), polyvinylpyrrolidone $\left(\mathrm{PVP}_{40}\right.$, average molecular weight of 40000$)$ and sodium hydroxide $(\mathrm{NaOH}, 98 \%)$ were used as received without additional purification. All samples were prepared in aqueous medium using twice-distilled water. We have adopted two preparative procedures; the first involves the samples (series SI) prepared at room temperature $\left(20^{\circ} \mathrm{C}\right)$, the second concerns the ones prepared at $95^{\circ} \mathrm{C}$ (series SII).

In a typical synthesis, an appropriate quantity of zinc salt precursor (chloride or nitrate of $0.2 \mathrm{M}$ ) and a fixed mass of $1391 \mathrm{mg}$ of $\mathrm{PVP}_{40}$, used as a dispersing agent as well as stabilizer of the crystals produced, were dissolved in twice-distilled water. A given mass of $\mathrm{NaOH}$ base, obtained by varying the alkaline ratio $\mathrm{b}$ of $\mathrm{OH}^{-} / \mathrm{Zn}^{2+}$ from 0.5 to 4 , was added to the solution. A white precipitate was immediately formed in the mixture which was kept under vigorous stirring at $20^{\circ} \mathrm{C}$ for $20 \mathrm{~min}$ (series SI). Next, the $\mathrm{pH}$ value of each solution was measured and noted. For the second procedure (series SII), each sample was prepared in the same way as SI but additionally heated to and maintained at $95^{\circ} \mathrm{C}$ for $3 \mathrm{~h}$ under stirring. After cooling to room temperature, the resulting white precipitate (SI or SII) was centrifuged, washed several times with water and ethanol, and then dried in air at $60^{\circ} \mathrm{C}$ for $12 \mathrm{~h}$.

Once heat treatment of the samples was achieved, the powders were placed into crucible and annealed in air for $2 \mathrm{~h}$ at different temperatures in the range of $100-400{ }^{\circ} \mathrm{C}$.

\subsection{Characterization Techniques}

The X-ray powder diffraction (XRD) patterns were recorded on a Bruker D8 Advance apparatus with $\mathrm{Cu}\left(\mathrm{K}_{\alpha}\right)$ radiation $(\lambda=$ $1.5406 \AA$ ). XRD patterns of the recuperated powders were recorded in the scan range $2 \theta=5-85^{\circ}$. The average crystallite sizes were calculated from the width of the XRD peaks using the Scherrer formula. ${ }^{30}$

Fourier transform infrared (FT-IR) spectra were recorded on a Thermo Scientific Nicolet IR 200 spectrophotometer in the range of $400-4000 \mathrm{~cm}^{-1}$.

The photoluminescence (PL) measurements were carried out at room temperature using a Perkin-Elmer spectrophotometer (LS 55) with Xenon lamp source and $320 \mathrm{~nm}$ excitation wavelength.

\section{Results and Discussion}

3.1. Structure of the Samples and Photoluminescence of $\mathrm{ZnO}$

\subsubsection{Structural Study}

a) Samples Prepared at $95^{\circ} \mathrm{C}$ (SII)

XRD patterns of the powders synthesized at $95^{\circ} \mathrm{C}$ with different alkaline ratios are given in Fig. 1A,B).
For all the samples prepared with zinc nitrate (Fig. 1A), the XRD diffractograms are quite similar even though the alkaline ratio $b$ was varied in the range $1-4$. Interestingly, a new phase was formed at lower alkaline ratio $(b=1)$ for the samples synthesized with zinc chloride precursor (Fig. 1B); the intense diffraction peak appearing at the low diffraction angle of $11.23^{\circ}$ is a typical characteristic of a layered compound having a large inter-layer spacing. This phase was identified as chloride lamellar phase (CLP) which was formed at a lower $\mathrm{pH}$ value $(\sim 6.3)$. Note that no similar layered phase was obtained for the samples prepared with zinc nitrate precursor under the same conditions. This result clearly showed that zinc chloride and zinc nitrate have different behaviour that could be related to structural characteristics of the two lamellar phases associated with each of the precursors.

The peak positions of all the XRD patterns (except Fig. 1B for $b$ $=1$ ) are matching well with the data reported in JCPDS Card No. 36-1451 for the wurtzite zinc oxide. ${ }^{31,32}$ The XRD diagrams (Fig. 1A,B) reveal well-crystallized $\mathrm{ZnO}$ powder; the peak broadening indicated the nature of the small nanocrystals. Crystallite sizes of $\mathrm{ZnO}$ were estimated following the well-known Scherrer equation: $L=0.9 \lambda /(\beta \cos \theta)$ where $L$ represents crystallite size $(\AA)$,
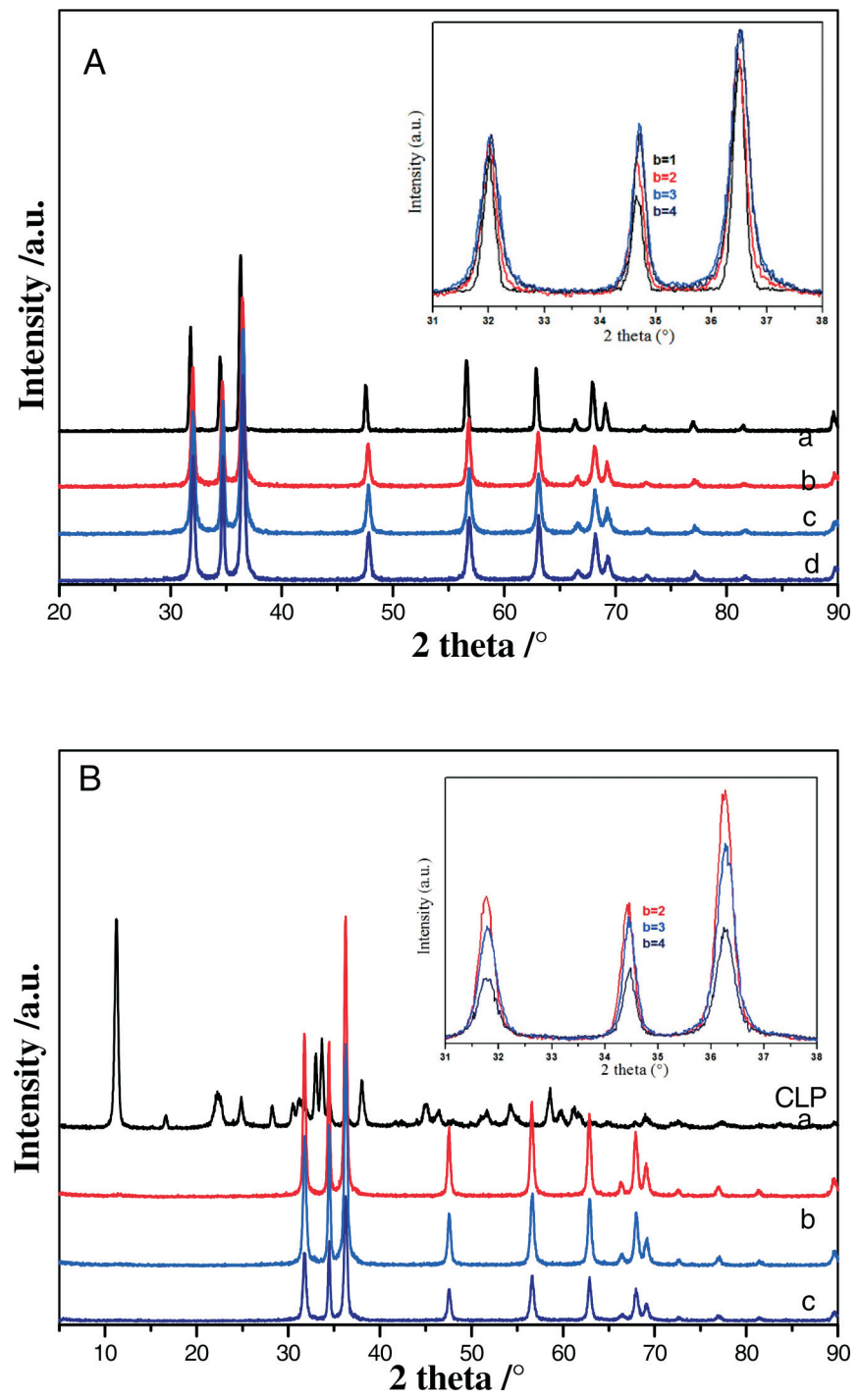

Figure $1 \mathrm{X}$-ray diffraction patterns of samples (SII) prepared at $95^{\circ} \mathrm{C}$ : (A) synthesized with zinc nitrate : $a(b=1), b(b=2), c(b=3), d(b=4) ;(B)$ synthesized with zinc chloride: CLP (chloride lamellar phase) $a(b=2), b$ $(b=3), c(b=4)$. The insets (A and $B)$ : zoom of the $\mathrm{ZnO}$ diffraction peaks in the $2 \theta$ range $30-40^{\circ}$. 
$\lambda$ is the wavelength of $\mathrm{Cu}(\mathrm{K} \alpha)$ radiation $(\AA)$ and $\beta$ is the corrected full width at half maximum (FWHM) of the diffraction peak. ${ }^{30}$

The average crystallite sizes of $\mathrm{ZnO}$ were calculated by considering the first three peaks (100), (002) and (101) and are found to decrease when the alkaline ratio was increased; $48 \mathrm{~nm}$ and 28-30 nm for $b=1$ and $b=4$, respectively, for both $Z N$ samples prepared with $\mathrm{Zn}\left(\mathrm{NO}_{3}\right)_{2} \cdot 6 \mathrm{H}_{2} \mathrm{O}$ and $\mathrm{ZC}$ ones synthesized using $\mathrm{ZnCl}_{2}$ salt (Table 1 ).

Note that the effect of the $\mathrm{pH}$ medium on $\mathrm{ZnO}$ crystallites sizes is not yet well clearly understood and contradictory results could be found in the literature. For instance, S.S. Alias et al. have reported results which are in accordance with ours. ${ }^{33}$ The authors prepared $\mathrm{ZnO}$ nanocrystals in methanol as solvent at $25^{\circ} \mathrm{C}$ under stirring for $2 \mathrm{~h}$ using $\mathrm{Zn}\left(\mathrm{CH}_{3} \mathrm{CO}_{2}\right)_{2} \cdot 2 \mathrm{H}_{2} \mathrm{O}(0.2 \mathrm{M})$ and $\mathrm{NaOH}$ solution $(1 \mathrm{M})$ as reactants in the $\mathrm{pH}$ range 6-13. They found that further increase in $\mathrm{OH}^{-}$concentration in $\mathrm{ZnO}(\mathrm{pH} 10$ and 11) reduced the crystallite sizes because $\mathrm{ZnO}$ can be dissolved when it reacted with excessive $\mathrm{OH}^{-}$ions.

On the other hand, M. J. Chithra et al. have synthesized $\mathrm{ZnO}$ nanoparticles by chemical precipitation in ethanol as solvent at $30{ }^{\circ} \mathrm{C}$ using zinc acetate $(0.2 \mathrm{M})$ and $\mathrm{NaOH}$. The authors have reported an opposite result; they have noted an increase in the crystallite sizes when the $\mathrm{pH}$ values increase, the calculated sizes were 13.8, 18.0, 24.7 and $33 \mathrm{~nm}$ for the samples obtained at $\mathrm{pH}$ values of $6,8,12$ and 13 , respectively. ${ }^{34}$

\section{b) Samples Prepared at $20^{\circ} \mathrm{C}(\mathrm{SI})$}

Powder X-ray diffraction patterns of as-prepared samples are shown in Fig. $2 A, B)$. For lower alkaline ratios $(b=0.5 ; 1)$, pure layered hydroxide zinc salts were formed: nitrate lamellar phase (NLP) was obtained applying $\mathrm{Zn}\left(\mathrm{NO}_{3}\right)_{2} \cdot 6 \mathrm{H}_{2} \mathrm{O}$ as precursor and chloride lamellar phase (CLP) was formed when $\mathrm{ZnCl}_{2}$ was used. All the corresponding XRD peaks of NLP and CLP (Fig. 2, $\mathrm{b}=0.5$ or 1 (Fig. 2A,B)) can be well indexed to monoclinic $\mathrm{Zn}_{5}(\mathrm{OH})_{8}\left(\mathrm{NO}_{3}\right)_{2} \cdot 2 \mathrm{H}_{2} \mathrm{O}$ phase and hexagonal $\mathrm{Zn}_{5}(\mathrm{OH})_{8} \mathrm{Cl}_{2} \cdot \mathrm{H}_{2} \mathrm{O}$ phase, respectively, and neither product could be detected in each other. It is worth noting that no wulfingite $\varepsilon-\mathrm{Zn}(\mathrm{OH})_{2}$ phase was detected in all samples (Table 1).

Increasing the alkaline ratio $b$ to 2 led to the coexistence of $\mathrm{ZnO}$ and $\mathrm{Zn}_{5}(\mathrm{OH})_{8}\left(\mathrm{NO}_{3}\right)_{2} \cdot 2 \mathrm{H}_{2} \mathrm{O}$ phase (Fig. $2 \mathrm{~A}, \mathrm{~b}=2$ ) or $\mathrm{ZnO}$ and $\mathrm{Zn}_{5}(\mathrm{OH})_{8} \mathrm{Cl}_{2} \cdot \mathrm{H}_{2} \mathrm{O}$ phase (Fig. $2 \mathrm{~B}, \mathrm{~b}=2$ ). Further increasing the alkaline ratio to $\mathrm{b} \geq 3$, only $\mathrm{ZnO}$ is formed and the lamellar phases (NLP and CLP) disappear. This indicates that the formation reaction of zinc oxide is highly promoted under strongly basic conditions (Table 1) and then, the $\mathrm{ZnO}$ wurtzite phase is formed independent of the nature of the zinc precursor.

Furthermore, it is interesting to report that using $\mathrm{KOH}$ as a second base instead of $\mathrm{NaOH}$ led to identical results for the two
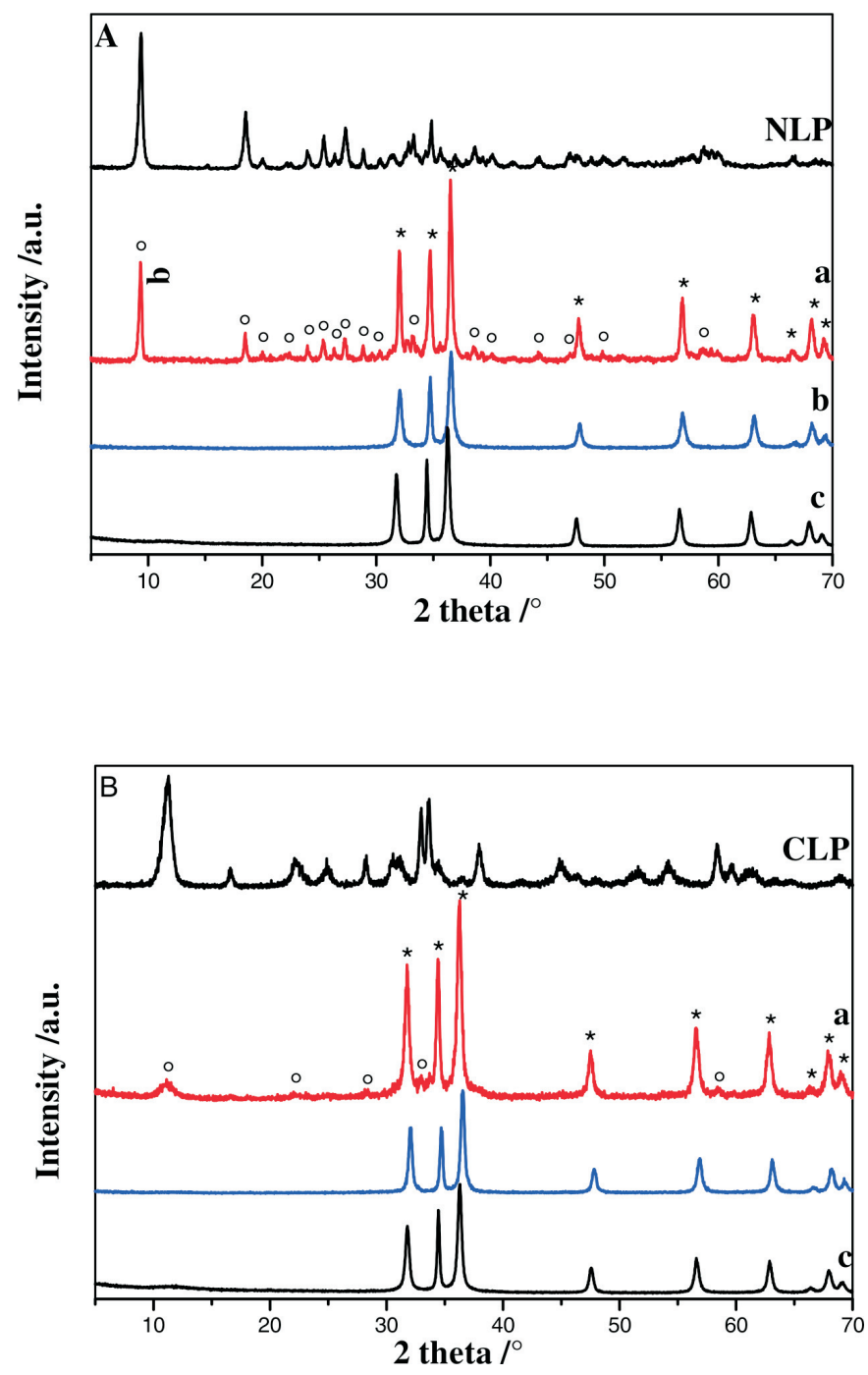

Figure $2 \mathrm{X}$-ray diffraction patterns of samples prepared at $20^{\circ} \mathrm{C}$ : (A) synthesized with zinc nitrate: NLP (Nitrate Lamellar Phase for $b=0.5$ or $\mathrm{b}=1) \mathrm{a}(\mathrm{b}=2), \mathrm{b}(\mathrm{b}=3), \mathrm{c}(\mathrm{b}=4) ;\left(^{\circ}\right)$ peaks of NLP , (*) peaks of $\mathrm{ZnO}$ wurtzite phase. (B) synthesized with zinc chloride: CLP (chloride lamellar phase for $b=0.5$ or $b=1) a(b=2), b(b=3), c(b=4) .\left(^{\circ}\right)$ peaks of CLP, $\left(^{*}\right)$ peaks of $\mathrm{ZnO}$.

series (SI and SII) indicating that the counter-ion of the strong base $\mathrm{MOH}(\mathrm{M}=\mathrm{Na}$ or $\mathrm{K})$ does not affect the products of the different reactions.

Based on this observed results, we suggest a possible reaction processes for the formation of $\mathrm{ZnO}$ and/or lamellar compounds as follows.

Table 1 Phase composition of samples (SI and SII) and calculated crystallite sizes of $\mathrm{ZnO}$ (SII).

\begin{tabular}{|c|c|c|c|c|}
\hline Sample * & $\begin{array}{l}\text { Alkaline ratio; } \\
\text { pH }\end{array}$ & $\begin{array}{c}\text { Phase composition }(\mathrm{SI}) \\
\text { prepared at } 20^{\circ} \mathrm{C}\end{array}$ & $\begin{array}{l}\text { Phase composition (SII) } \\
\text { prepared at } 95^{\circ} \mathrm{C}\end{array}$ & $\begin{array}{c}\text { (SII) average } \\
\text { crystallite size } / \mathrm{nm}\end{array}$ \\
\hline ZN0.5 & $0.5 ; 6.1$ & $\mathrm{Zn}_{5}(\mathrm{OH})_{8}\left(\mathrm{NO}_{3}\right)_{2} \cdot 2 \mathrm{H}_{2} \mathrm{O}$ & - & - \\
\hline ZN1 & $1 ; 6.4$ & $\mathrm{Zn}_{5}(\mathrm{OH})_{8}\left(\mathrm{NO}_{3}\right)_{2} \cdot 2 \mathrm{H}_{2} \mathrm{O}$ & $\mathrm{ZnO}$ & 48 \\
\hline $\mathrm{ZN} 2$ & $2 ; 9.9$ & $\mathrm{Zn}_{5}(\mathrm{OH})_{8}\left(\mathrm{NO}_{3}\right)_{2} \cdot 2 \mathrm{H}_{2} \mathrm{O}+\mathrm{ZnO}$ & $\mathrm{ZnO}$ & 34 \\
\hline ZN3 & $3 ; 13$ & $\mathrm{ZnO}$ & $\mathrm{ZnO}$ & 28 \\
\hline ZN4 & $4 ; 13.3$ & $\mathrm{ZnO}$ & $\mathrm{ZnO}$ & 30 \\
\hline ZC0.5 & $0.5 ; 6.1$ & $\mathrm{Zn}_{5}(\mathrm{OH})_{8} \mathrm{Cl}_{2} \cdot \mathrm{H}_{2} \mathrm{O}$ & - & - \\
\hline $\mathrm{ZC} 1$ & $1 ; 6.3$ & $\mathrm{Zn}_{5}(\mathrm{OH})_{8} \mathrm{Cl}_{2} \cdot \mathrm{H}_{2} \mathrm{O}$ & $\mathrm{Zn}_{5}(\mathrm{OH})_{8} \mathrm{Cl}_{2} \cdot \mathrm{H}_{2} \mathrm{O}$ & - \\
\hline $\mathrm{ZC} 2$ & $2 ; 10.9$ & $\mathrm{Zn}_{5}(\mathrm{OH})_{8} \mathrm{Cl}_{2} \cdot \mathrm{H}_{2} \mathrm{O}+\mathrm{ZnO} \mathrm{ZnO}$ & $\mathrm{ZnO}$ & 31 \\
\hline $\mathrm{ZC} 3$ & $3 ; 13.1$ & $\mathrm{ZnO}$ & $\mathrm{ZnO}$ & 28 \\
\hline ZC4 & $4 ; 13.4$ & $\mathrm{ZnO}$ & $\mathrm{ZnO}$ & 28 \\
\hline
\end{tabular}

\footnotetext{
* $\mathrm{ZN}$ prepared using $\mathrm{Zn}\left(\mathrm{NO}_{3}\right)_{2} \cdot 6 \mathrm{H}_{2} \mathrm{O}$; $\mathrm{ZC}$ prepared using $\mathrm{ZnCl}_{2}$.
} 
$\mathrm{b}=1\left(\left[\mathrm{OH}^{-}\right] /\left[\mathrm{Zn}^{2+}\right]=1\right)$

$\left(\mathrm{Zn}^{2+}+2 \mathrm{Cl}^{-}\right)+\left(\mathrm{M}^{+}+\mathrm{OH}^{-}\right)+1 / 8 \mathrm{H}_{2} \mathrm{O} \longrightarrow$

$1 / 8 \mathrm{Zn}_{5}(\mathrm{OH})_{8} \mathrm{Cl}_{2} \cdot \mathrm{H}_{2} \mathrm{O}+3 / 8\left(\mathrm{Zn}^{2+}+2 \mathrm{Cl}^{-}\right)+\left(\mathrm{M}^{+}+\mathrm{Cl}^{-}\right)$

$\left(\mathrm{Zn}^{2+}+2 \mathrm{NO}_{3}^{-}\right)+\left(\mathrm{M}^{+}+\mathrm{OH}^{-}\right)+1 / 4 \mathrm{H}_{2} \mathrm{O} \longrightarrow$

$1 / 8 \mathrm{Zn}_{5}(\mathrm{OH})_{8}\left(\mathrm{NO}_{3}\right)_{2} \cdot 2 \mathrm{H}_{2} \mathrm{O}+3 / 8\left(\mathrm{Zn}^{2+}+2 \mathrm{NO}_{3}^{-}\right)+\left(\mathrm{M}^{+}+\mathrm{NO}_{3}^{-}\right)$

$\mathrm{b}=2\left(\left[\mathrm{OH}^{-}\right] /\left[\mathrm{Zn}^{2+}\right]=2\right)$

$\left(\mathrm{Zn}^{2+}+2 \mathrm{Cl}^{-}\right)+2\left(\mathrm{M}^{+}+\mathrm{OH}^{-}\right)$

$1 / 8 \mathrm{Zn}_{5}(\mathrm{OH})_{8} \mathrm{Cl}_{2} \cdot \mathrm{H}_{2} \mathrm{O}+3 / 8 \mathrm{ZnO}+1 / 4\left(\mathrm{M}^{+}+\mathrm{OH}^{-}\right)+7 / 4\left(\mathrm{M}^{+}+\right.$

$\left.\mathrm{Cl}^{-}\right)+1 / 4 \mathrm{H}_{2} \mathrm{O}$.

$\left(\mathrm{Zn}^{2+}+2 \mathrm{NO}_{3}^{-}\right)+2\left(\mathrm{M}^{+}+\mathrm{OH}^{-}\right)$

$1 / 8 \mathrm{Zn}_{5}(\mathrm{OH})_{8}\left(\mathrm{NO}_{3}\right)_{2} \cdot 2 \mathrm{H}_{2} \mathrm{O}+3 / 8 \mathrm{ZnO}+1 / 4\left(\mathrm{M}^{+}+\mathrm{OH}^{-}\right)+$

$7 / 4\left(\mathrm{M}^{+}+\mathrm{NO}_{3}^{-}\right)+1 / 8 \mathrm{H}_{2} \mathrm{O}$.

$\mathrm{b}=\mathrm{n} \geq 3\left(\left[\mathrm{OH}^{-}\right] /\left[\mathrm{Zn}^{2+}\right] \geq 3\right)$

$\left(\mathrm{Zn}^{2+}+2 \mathrm{X}^{-}\right)+\mathbf{n}\left(\mathrm{M}^{+}+\mathrm{OH}^{-}\right)$

$\mathrm{ZnO}+2\left(\mathrm{M}^{+}+\mathrm{X}^{-}\right)+(\mathrm{n}-2)\left(\mathrm{M}^{+}+\mathrm{OH}^{-}\right)+\mathrm{H}_{2} \mathrm{O}$ with $\mathrm{X}^{-}=\mathrm{NO}_{3}^{-}$ or $\mathrm{Cl}^{-}$

c) Structure of Lamellar Phases

The chloride lamellar phase $\mathrm{Zn}_{5}(\mathrm{OH})_{8} \mathrm{Cl}_{2} \cdot \mathrm{H}_{2} \mathrm{O}$ (CLP) crystallizes in the space group $\mathrm{R}-3 \mathrm{~m}$ with the following hexagonal cell parameters: $\mathrm{a}=\mathrm{b}=6.3412 \AA, \mathrm{c}=23.650 \AA, \alpha=\beta=90^{\circ}, \gamma=$ $120^{\circ}{ }^{35}$ A projection of the atomic arrangement of CLP, along the $\mathrm{b}$ axis, is given in Fig. 3 .

The CLP structure consists of infinite layers perpendicular to the c direction and separated by $7.88 \AA$ (c/3). These sheets are formed by interconnected $\mathrm{Zn}(\mathrm{OH})_{6}$ octahedra. The water molecules and $\mathrm{Zn}(\mathrm{OH})_{3} \mathrm{Cl}$ tetrahedra are located between these sheets.

The nitrate lamellar phase (NLP), $\mathrm{Zn}_{5}(\mathrm{OH})_{8}\left(\mathrm{NO}_{3}\right)_{2} \cdot 2 \mathrm{H}_{2} \mathrm{O}$, belongs to the space group $\mathrm{C} 2 / \mathrm{m}$ with a monoclinic cell: $a=$ $19.48, b=6.238, c=5.517 \mathrm{~A}^{\circ}, \beta=83.28 \circ$ (PDF card No. 72-0627).$^{36}$

A projection of the NLP structure is illustrated in Fig. 4. It shows infinite parallel layers of $\mathrm{Zn}(\mathrm{OH})_{6}$ octahedra. The zinc tetrahedra $\mathrm{Zn}(\mathrm{OH})_{3}\left(\mathrm{O}_{\text {water }}\right)$ and nitrate ions are inserted between theses sheets which are related by weak hydrogen bonds. The inter-layer distance is about $9.74 \AA$ corresponding to $\mathrm{a} / 2$. Compared to the CLP structure, the NLP compound exhibits a longer distance between the sheets and its nitrate units are not involved in the coordination sphere of the zinc cation unlike CLP compound where the chloride ion is actually connected to zinc tetrahedron $\left(\mathrm{Zn}(\mathrm{OH})_{3} \mathrm{Cl}\right)$. Based on these observations, $\mathrm{Zn}_{5}(\mathrm{OH})_{8} \mathrm{Cl}_{2} \cdot \mathrm{H}_{2} \mathrm{O}$ solid may have a more rigid framework and thus we can expect a higher thermal stability for CLP. This is why, unlike $\mathrm{Zn}_{5}(\mathrm{OH})_{8} \mathrm{Cl}_{2} \cdot \mathrm{H}_{2} \mathrm{O}$, the NLP phase was not obtained via the second synthesis procedure realized at $95{ }^{\circ} \mathrm{C}$ (series SII, $\mathrm{b}=1$ ) because of its low stability: $\mathrm{Zn}_{5}(\mathrm{OH})_{8}\left(\mathrm{NO}_{3}\right)_{2} \cdot 2 \mathrm{H}_{2} \mathrm{O}$ may decompose at $95^{\circ} \mathrm{C}$ to produce $\mathrm{ZnO}$.

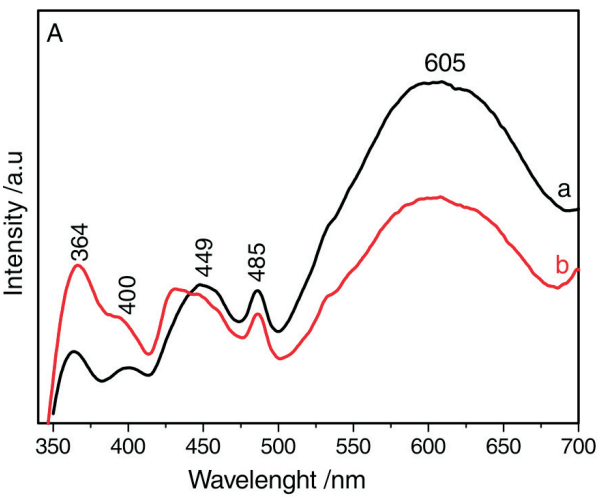

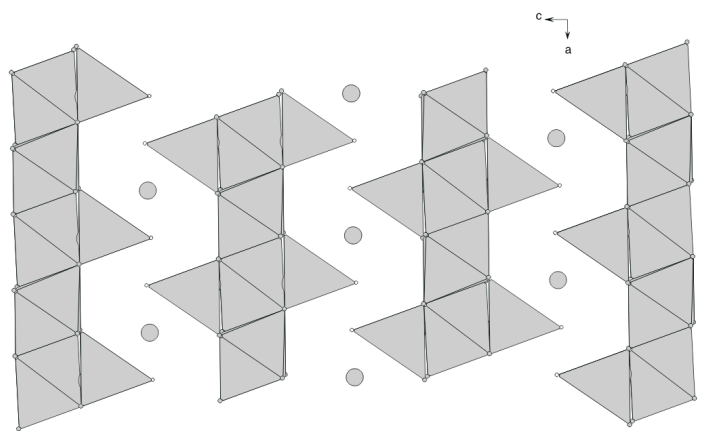

Figure 3 A projection of $\mathrm{Zn}_{5}(\mathrm{OH})_{8} \mathrm{Cl}_{2} \cdot \mathrm{H}_{2} \mathrm{O}$ structure (grey circles: oxygen atoms of water molecules, hatched polyhedra: $\mathrm{Zn}(\mathrm{OH})_{6}$ octahedra, simple polyhedra: $\mathrm{Zn}(\mathrm{OH})_{3} \mathrm{Cl}$ tetrahedra)

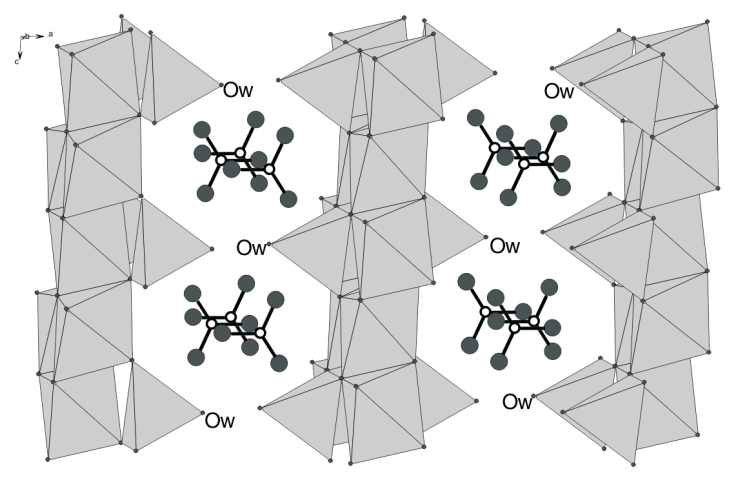

Figure 4 A projection of $\mathrm{Zn}_{5}(\mathrm{OH})_{8}\left(\mathrm{NO}_{3}\right)_{2} \cdot 2 \mathrm{H}_{2} \mathrm{O}$ structure (dark circles: oxygen atoms of nitrate units, empty circles: nitrogen atoms, hatched polyhedra: $\mathrm{Zn}(\mathrm{OH})_{6}$ octahedra, simple polyhedra: $\mathrm{Zn}(\mathrm{OH})_{3}\left(\mathrm{O}_{\text {water }}\right)$ tetrahedra, Ow: oxygen atom of water molecule).

\subsubsection{Photoluminescence Analysis of $\mathrm{ZnO}$}

ZN3(SII) and ZC3(SII) samples prepared with different zinc salts and corresponding to hexagonal zinc oxide were selected for the photoluminescence (PL) analysis. Their room temperature PL spectra are given in Fig. 5.

Generally, $\mathrm{ZnO}$ wurtzite photoluminescence spectrum typically exhibits emission bands in the near UV and in the visible range. $^{37,38}$ The UV emission $(360-380 \mathrm{~nm})$ is associated with the radiative recombination of an electron from the conduction band with a hole located in the valence band (band-edge emission) or in a trap near the valence band (near-band-edge emission). The visible luminescence of $\mathrm{ZnO}$ contains violet-blue (390-480 nm), green (500-520 nm), yellow-orange (560-600 nm) and red (650-670 $\mathrm{nm})$ bands. The origin of the visible luminescence is frequently related to numerous $\mathrm{ZnO}$ defects such as oxygen vacancies $\left(\mathrm{V}_{\mathrm{O}}\right)$, zinc vacancies $\left(\mathrm{V}_{\mathrm{Zn}}\right)$, oxygen intersticials

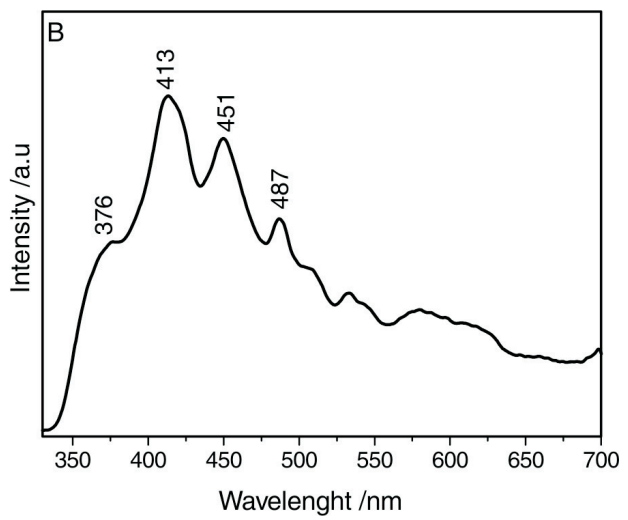

Figure 5 Room temperature photoluminescence spectra of $\mathrm{ZnO}\left(\lambda_{\mathrm{exc}}=320 \mathrm{~nm}\right)$. (A): (a) for ZN3(SII) and (b) for ZC3(SII) ; (B): ZN3(SII) annealed at $300{ }^{\circ} \mathrm{C}$ for $2 \mathrm{~h}$. 
(Oi), zinc intersticials $(\mathrm{Zni})$, antisite oxygen $\left(\mathrm{O}_{\mathrm{Zn}}\right)$ and extrinsic impurities. ${ }^{39,40}$

ZN3(SII) and ZC3(SII) exhibit comparable luminescence spectra not only in the UV domain $(364 \mathrm{~nm})$ but also in the visible region characterized by a dominant large band in 500-690 nm, centred at $\sim 605 \mathrm{~nm}$ (Fig. 5A). Nevertheless, ZC3(SII) presents a stronger UV band at $364 \mathrm{~nm}$ ascribed to the free exciton recombination but emits less intense visible bands. Generally, $\mathrm{ZnO}$ nanostructures with relatively small size and abundant structural defects present strong emissions in the visible region. ${ }^{40,41}$ Comparatively, the intense UV emission band joined to the weak visible emission bands may give evidence for the better crystallinity of the $\mathrm{ZnO}$ prepared with the zinc chloride salt. Therefore, $\mathrm{ZnO}$ nanocrystals of $\mathrm{ZN} 3$ (SII) sample are formed with more intrinsic defects that are, manifestly, dependent on the nature of the zinc salt precursor.

In the purpose to improve the $\mathrm{ZN} 3$ (SII) cristallinity, this sample was annealed at $300{ }^{\circ} \mathrm{C}$ for $2 \mathrm{~h}$ and then its PL spectrum was recorded (Fig. 5B). Interestingly, the thermally treated nanocrystals show that the UV emission band $(\sim 376 \mathrm{~nm})$ becomes more intense and the large visible emission in the range 500-690 nm becomes remarkably reduced.

It was thus shown that the annealing process improved the ZN3(SII) crystallinity and minimized the number of its structural defects. ${ }^{42}$

\subsection{Thermal Decomposition of Lamellar Phases}

In order to investigate the thermal stabilities of the tow lamellar intermediate phases, diffraction patterns of annealed CLP and NLP samples at various temperatures are recorded (Figs. 6 and 7). For each phase, we considered only one sample that underwent successive thermal treatments at different temperatures.

\subsubsection{Chloride Lamellar Phase (CLP)}

The CLP diffractogram of the sample heated at $100^{\circ} \mathrm{C}$ and the non-annealed one (Fig. 6) are identical and no structural change was observed. When the annealing temperature was increased to $250^{\circ} \mathrm{C}$, the $\mathrm{CLP}\left(\mathrm{Zn}_{5}(\mathrm{OH})_{8} \mathrm{Cl} 2 . \mathrm{H}_{2} \mathrm{O}\right)$ was partially decomposed and three phases were obtained, namely, CLP, $\mathrm{ZnO}$ wurtzite and $\beta-\mathrm{Zn}(\mathrm{OH}) \mathrm{Cl}$ which was identified by its most intense diffraction peak appearing at $15.7^{\circ}$ corresponding to the interreticular distance d $\left(\begin{array}{lll}0 & 0\end{array}\right)=0.565 \mathrm{~nm}\left(\right.$ Fig. 6, b).$^{35}$

The same previous three phases were still detected when the sample was annealed at $300^{\circ} \mathrm{C}$ but we noticed a narrowing of the CLP diffraction peaks widths with a very weak shift towards the higher $2 \theta$ angles (Fig. 6, c). Further increasing the annealing temperature to $350{ }^{\circ} \mathrm{C}$ led to the disappearance of $\beta-\mathrm{Zn}(\mathrm{OH}) \mathrm{Cl}$ and the presence of a mixture of the two previous phases that appear with a remarkable disproportionate amount; a very minor amount of the CLP phase and a major amount of the $\mathrm{ZnO}$ phase (Fig. 6, d).

The XRD pattern in Fig. 6 (e) shows that only the diffraction peaks of $\mathrm{ZnO}$ wurtzite are detected after annealing at $400{ }^{\circ} \mathrm{C}$ for $2 \mathrm{~h}$ suggesting the complete decomposition of $\mathrm{Zn}_{5}(\mathrm{OH})_{8} \mathrm{Cl}_{2} \cdot \mathrm{H}_{2} \mathrm{O}$.

Based on these observed results, it is possible to propose the following reaction processes to account for the thermal decomposition of $\mathrm{Zn}_{5}(\mathrm{OH})_{8} \mathrm{Cl}_{2} \cdot \mathrm{H}_{2} \mathrm{O}$ lamellar phase :

$\mathrm{Zn}_{5}(\mathrm{OH})_{8} \mathrm{Cl}_{2} \cdot \mathrm{H}_{2} \mathrm{O} \stackrel{\left(20^{\circ} \mathrm{C}-100^{\circ} \mathrm{C}\right)(2 \mathrm{~h})}{\rightleftharpoons} \mathrm{Zn}_{5}(\mathrm{OH})_{8} \mathrm{Cl}_{2} \cdot \mathrm{H}_{2} \mathrm{O}$.

$\mathrm{Zn}_{5}(\mathrm{OH})_{8} \mathrm{Cl}_{2} \cdot \mathrm{H}_{2} \mathrm{O} \stackrel{\left(250^{\circ} \mathrm{C}-300^{\circ} \mathrm{C}\right)(2 \mathrm{~h})}{\rightleftharpoons} 2 \mathrm{Zn}(\mathrm{OH}) \mathrm{Cl}+3 \mathrm{ZnO}+4 \mathrm{H}_{2} \mathrm{O}_{(\mathrm{g})}$ $\stackrel{\left(350^{\circ} \mathrm{C}\right)(2 \mathrm{~h})}{\underset{+4 \mathrm{H}_{2} \mathrm{O}_{(\mathrm{g})}}{\leftrightarrows}} 5 \mathrm{ZnO}+2 \mathrm{HCl}_{(\mathrm{g})}+4 \mathrm{H}_{2} \mathrm{O}_{(\mathrm{g})} \stackrel{\left(400^{\circ} \mathrm{C}\right)(2 \mathrm{~h})}{\longrightarrow} 5 \mathrm{ZnO}+2 \mathrm{HCl}_{(\mathrm{g})}$

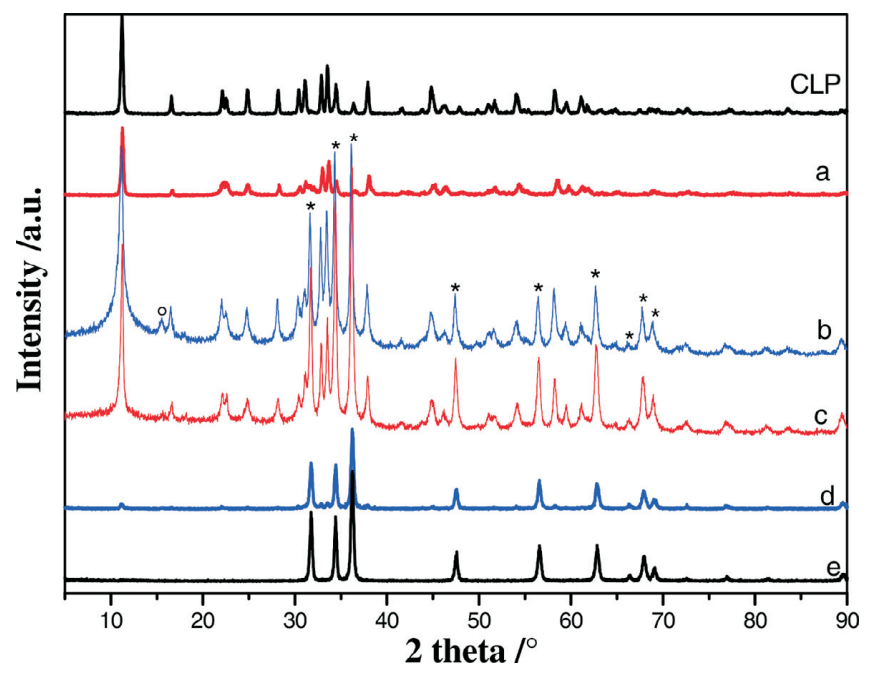

Figure 6 XRD powder patterns of chloride lamellar phase (CLP) annealed for $2 \mathrm{~h}$ at different temperatures: CLP at room temperature, a $\left(100^{\circ} \mathrm{C}\right), \mathrm{b}\left(250^{\circ} \mathrm{C}\right), \mathrm{c}\left(300^{\circ} \mathrm{C}\right), \mathrm{d}\left(350^{\circ} \mathrm{C}\right), \mathrm{e}\left(400^{\circ} \mathrm{C}\right) ;\left(^{\circ}\right)$ peak of $\beta-\mathrm{Zn}(\mathrm{OH}) \mathrm{Cl}$ , $\left(^{*}\right)$ peaks of $\mathrm{ZnO}$ wurtzite phase.

\subsubsection{Nitrate Lamellar Phase (NLP)}

The X-ray powders patterns of NLP sample annealed for $2 \mathrm{~h}$ at various temperatures are given in Fig. 7. The sample heated at $100{ }^{\circ} \mathrm{C}$ and the non-annealed one have the same diffraction pattern corresponding to $\mathrm{Zn}_{5}(\mathrm{OH})_{8}\left(\mathrm{NO}_{3}\right)_{2} \cdot 2 \mathrm{H}_{2} \mathrm{O}$ (NLP). Increasing the temperature to $150{ }^{\circ} \mathrm{C}(\mathrm{Fig} .7, \mathrm{~b})$ shows the complete disappearance of the NLP phase that decomposes into a mixture of $\mathrm{ZnO}$ and monoclinic $\mathrm{Zn}_{3}(\mathrm{OH})_{4}\left(\mathrm{NO}_{3}\right)_{2}$ (S.G : P21/C) having a most intense peak appearing at $12.9^{\circ}$ and corresponding to $\mathrm{d}_{(100)} \cdot{ }^{43}$

The XRD patterns of the sample heated at $200{ }^{\circ} \mathrm{C}$ and $250{ }^{\circ} \mathrm{C}$ (Fig. 7, c and d) show the disappearance of $\mathrm{Zn}_{3}(\mathrm{OH})_{4}\left(\mathrm{NO}_{3}\right)_{2}$ and the formation of wurtzite zinc oxide which exhibits intense and well-defined diffraction peaks indicating the improved crystallization of $\mathrm{ZnO}$ nanocrystals after annealing at these temperatures.

In view of these observations and based on some previous published works, ${ }^{44,45}$ we can propose the decomposition reactions as follows:

$\mathrm{Zn}_{5}(\mathrm{OH})_{8}\left(\mathrm{NO}_{3}\right)_{2} \cdot 2 \mathrm{H}_{2} \mathrm{O} \stackrel{\left(20-100^{\circ} \mathrm{C}\right)(2 \mathrm{~h})}{=} \mathrm{Zn}_{5}(\mathrm{OH})_{8}\left(\mathrm{NO}_{3}\right)_{2} \cdot 2 \mathrm{H}_{2} \mathrm{O}$.

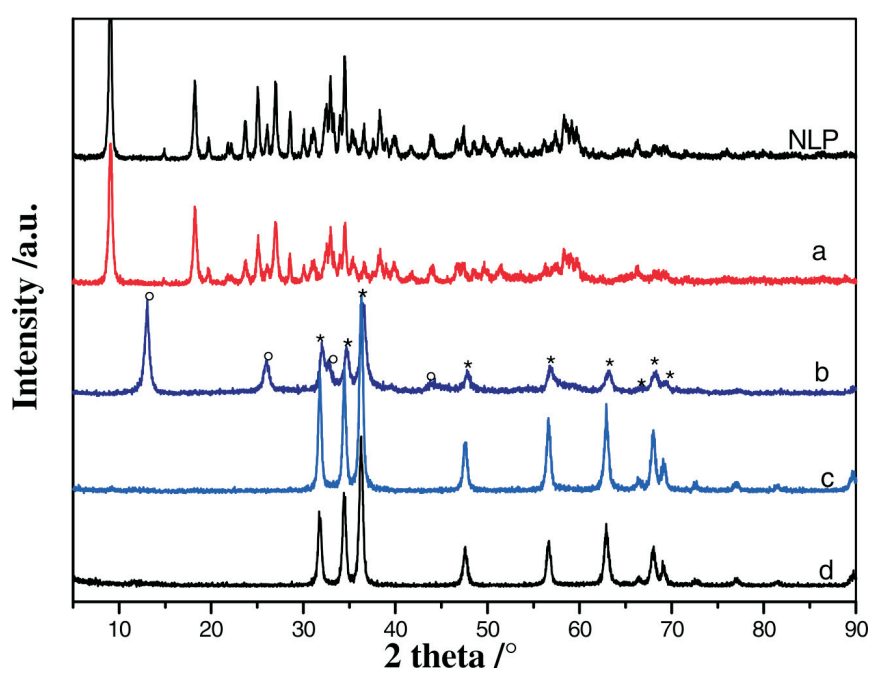

Figure 7 XRD powder patterns of nitrate lamellar phase (NLP) heated for $2 \mathrm{~h}$ at different temperatures: NLP at room temperature, a $\left(100{ }^{\circ} \mathrm{C}\right), \mathrm{b}$ $\left(150{ }^{\circ} \mathrm{C}\right), \mathrm{c}\left(200^{\circ} \mathrm{C}\right), \mathrm{d}\left(250^{\circ} \mathrm{C}\right) ;\left({ }^{\circ}\right)$ peaks of $\mathrm{Zn}_{3}(\mathrm{OH})_{4}\left(\mathrm{NO}_{3}\right)_{2},\left(^{*}\right)$ peaks of $\mathrm{ZnO}$ wurtzite phase. 

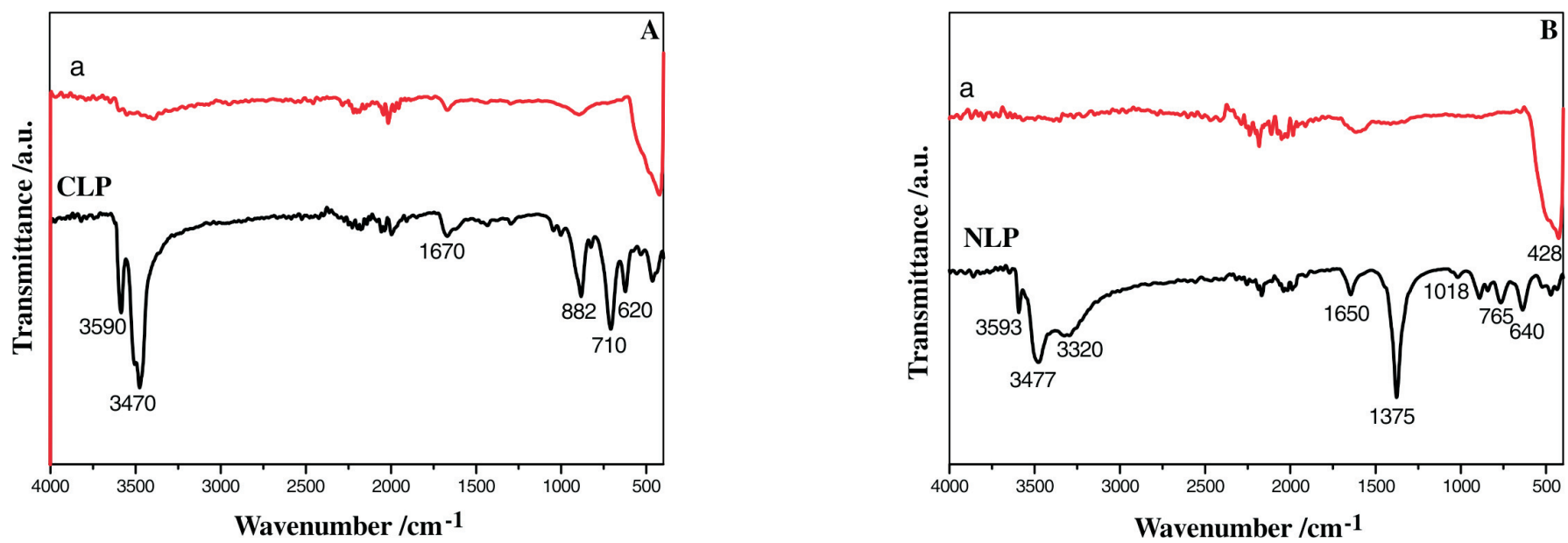

Figure 8 FTIR spectra of lamellar phases: (A) CLP: at room temperature, (a) CLP after annealing up to $400{ }^{\circ} \mathrm{C}$. (B) NLP: at room temperature, (a) NLP after annealing up to $250{ }^{\circ} \mathrm{C}$.

$$
\begin{aligned}
& \mathrm{Zn}_{5}(\mathrm{OH})_{8}\left(\mathrm{NO}_{3}\right)_{2} \cdot 2 \mathrm{H}_{2} \mathrm{O} \stackrel{\left(150^{\circ} \mathrm{C}\right)(2 \mathrm{~h})}{\longrightarrow} \mathrm{Zn}_{3}(\mathrm{OH})_{4}\left(\mathrm{NO}_{3}\right)_{2}+2 \mathrm{ZnO}+ \\
& 4 \mathrm{H}_{2} \mathrm{O}_{(\mathrm{g})} \stackrel{\left(200-250^{\circ} \mathrm{C}\right)(2 \mathrm{~h})}{\longrightarrow} 5 \mathrm{ZnO}+5 \mathrm{H}_{2} \mathrm{O}_{(\mathrm{g})}+2 \mathrm{HNO}_{3(\mathrm{~g})} .
\end{aligned}
$$

It can be seen from this qualitative thermal study of the intermediate lamellar phases that the CLP presents the highest thermal stability. In fact, $\mathrm{Zn}_{5}(\mathrm{OH})_{8} \mathrm{Cl}_{2} \cdot \mathrm{H}_{2} \mathrm{O}$ is completely decomposed into $\mathrm{ZnO}$ only when the annealing temperature exceeds $350^{\circ} \mathrm{C}$. On the other hand, $\mathrm{Zn}_{5}(\mathrm{OH})_{8}\left(\mathrm{NO}_{3}\right)_{2} \cdot 2 \mathrm{H}_{2} \mathrm{O}$ (NLP) is totally transformed, at only $150{ }^{\circ} \mathrm{C}$, into $\mathrm{ZnO}$ and $\mathrm{Zn}_{3}(\mathrm{OH})_{4}\left(\mathrm{NO}_{3}\right)_{2}$ which is wholly decomposed into $\mathrm{ZnO}$ when the temperature reaches $200-250{ }^{\circ} \mathrm{C}$.

These results are in good accordance with the structural characteristics of the lamellar compounds and mainly explain why the zinc salt precursors lead to different reaction products when the synthesis process was realized at $95{ }^{\circ} \mathrm{C}$ using lower alkaline ratio (SII $(b=1)$ ).

\subsection{FT-IR Spectroscopy Analysis}

FTIR spectra (Fig. 8) of the lamellar phases were recorded and analyzed. They are also in good accordance with the structural characteristics of the two compounds, not only for the no annealed samples but also for those heated up to the highest annealing temperature; $400^{\circ} \mathrm{C}$ for CLP and $250^{\circ} \mathrm{C}$ for NLP. Thus, the infrared spectrum of $\mathrm{Zn}_{5}(\mathrm{OH})_{8} \mathrm{Cl}_{2} \cdot \mathrm{H}_{2} \mathrm{O}$ (Fig. 8A) contains bands in the range $3600-3400 \mathrm{~cm}^{-1}$ corresponding to the stretching vibrations of $\mathrm{OH}$ groups; the sharp band at $3590 \mathrm{~cm}^{-1}$ may be assigned to the vibrations of hydroxyl units and the strong one at around $3470 \mathrm{~cm}^{-1}$ can be ascribed to the $\mathrm{OH}$ stretching vibrations of the water molecules, the medium intense band at $1670 \mathrm{~cm}^{-1}$ is due to the bending vibrations of the $\mathrm{H}_{2} \mathrm{O}$ molecules. ${ }^{46}$ The intense bands at 882 and $710 \mathrm{~cm}^{-1}$ are due to stretching vibration modes of $\mathrm{Zn}-\mathrm{Cl}$ units and the weak and sharp band at $620 \mathrm{~cm}^{-1}$ is assigned to the $\delta$-mode of the O-H groups. ${ }^{47-49}$ The CLP sample annealed up to $400{ }^{\circ} \mathrm{C}$ presents a typical infrared spectrum (Fig. 8A, a) of $\mathrm{ZnO}$ wurtzite phase identifiable by its characteristic strong band located at about $430 \mathrm{~cm}^{-1}$.

The FTIR spectrum of $\mathrm{Zn}_{5}(\mathrm{OH})_{8}\left(\mathrm{NO}_{3}\right)_{2} \cdot 2 \mathrm{H}_{2} \mathrm{O}$ (Fig. 8B) mainly contains the specific IR frequencies of the nitrate groups and the hydroxyl units. The three bands on the higher frequency side of the spectrum located at 3593, 3477 and $3320 \mathrm{~cm}^{-1}$ are attributed to the $\mathrm{OH}$ stretching vibrations of the layer hydroxyls and the water molecules; the weak band at around $1650 \mathrm{~cm}^{-1}$ is ascribed to the bending vibrations of $\mathrm{H}_{2} \mathrm{O}$ species. The strong sharp band at $1375 \mathrm{~cm}^{-1}$, the weak ones at 840 and $765 \mathrm{~cm}^{-1}$ and the very weak peak at about $1018 \mathrm{~cm}^{-1}$ are due to nitrate groups and correspond to their asymmetric stretch $\left(v_{3}\right)$, the asymmetric $\left(v_{2}\right)$ and symmetric $\left(v_{4}\right)$ deformations and symmetric stretch $\left(v_{1}\right)$, respectively. ${ }^{45,48}$ Finally the weak peak at around $640 \mathrm{~cm}^{-1}$ can be assigned to $\delta(\mathrm{Zn}-\mathrm{OH})$ bending mode. ${ }^{49}$

The infrared spectrum (Fig. 8B, a) of NLP annealed up to only $250{ }^{\circ} \mathrm{C}$ shows the intense band located at about $428 \mathrm{~cm}^{-1}$ that unambiguously corresponds to $\mathrm{Zn}-\mathrm{O}$ bond vibration of the zinc oxide wurtzite phase..$^{50}$

In view of these spectroscopic analyses, it is interesting to note that the obtained results are in good agreement with those of the thermal decomposition study and once again confirm the lower stability of NLP compared to CLP.

\section{Conclusion}

Using the aqueous precipitation method, we have principally demonstrated the important effect of the zinc precursor nature to condition the reaction products; zinc oxide or lamellar phases. In a similar way, the role of the reaction temperature and the basicity on the $\mathrm{ZnO}$ nanocrystals synthesis has been demonstrated.

When the alkaline ratio $b=[\mathrm{OH}-] /\left[\mathrm{Zn}^{2+}\right]$ is lower $(0.5 \leq \mathrm{b} \leq 1$; $6 \leq \mathrm{pH} \leq 6.5), \mathrm{ZnCl}_{2}$ and $\mathrm{Zn}\left(\mathrm{NO}_{3}\right)_{2} \cdot 6 \mathrm{H}_{2} \mathrm{O}$ precursors present different behaviour and lead to distinct reaction products not only at room temperature suitable for the formation, respectively, of $\mathrm{Zn}_{5}(\mathrm{OH})_{8} \mathrm{Cl}_{2} \cdot \mathrm{H}_{2} \mathrm{O}(\mathrm{CLP})$ and $\mathrm{Zn}_{5}(\mathrm{OH})_{8}\left(\mathrm{NO}_{3}\right)_{2} \cdot 2 \mathrm{H}_{2} \mathrm{O}$ (NLP) lamellar phases, but also at $95^{\circ} \mathrm{C}$ to obtain $\mathrm{ZnO}$ wurtzite or $\mathrm{Zn}_{5}(\mathrm{OH})_{8} \mathrm{Cl}_{2} \cdot \mathrm{H}_{2} \mathrm{O}$ which exhibits a better thermal stability compared to NLP.

Increasing the alkaline ratio $(2 \leq \mathrm{b} \leq 4)$ leads only to $\mathrm{ZnO}$ formation regardless of the zinc salt precursor and the reaction temperature $\left(20^{\circ} \mathrm{C}\right.$ or $\left.95^{\circ} \mathrm{C}\right)$.

In view of these results, we envisage to extend the present study to investigate the effect of the previous synthesis parameters on the size and the morphology transformation of the obtained nanocrystals for both $\mathrm{ZnO}$ and intermediate phases.

\section{Acknowledgements}

The authors are very thankful to Professor K. Horchani (Laboratoire de Physico-Chimie des Matériaux Minéraux et leurs Applications, Technopole de Borj Cedria, Soliman, Tunisia) for her help in acquiring the photoluminescence data.

\section{${ }^{8}$ ORCID ID}

T. B. Chaabane: orcid.org/0000-0002-0402-0450 


\section{References}

1 S.J. Pearton and F. Ren, Advances in ZnO-based materials for light emitting diodes, Curr. Opin. Chem. Eng., 2014, 3, 51-55.

2 H. Dae-Kue, O. Min-Suk, L. Jae-Hong and P. Seong-Ju, ZnO thin films and light-emitting diodes, J. Phys. D: Appl. Phys., 2007, 40, R387.

3 K. Ando, H. Saito, Z. Jin, T. Fukumura, M. Kawasaki, Y. Matsumoto and $\mathrm{H}$. Koinuma, Large magneto-optical effect in an oxide diluted magnetic semiconductor Zn1-xCoxO, Appl. Phys. Lett, 2001, 78, 2700-2702.

4 M.H. Huang, S. Mao, H. Feick, H.Q. Yan, Y.Y. Wu, H. Kind, E. Weber, R. Russo and P.D. Yang, Room-temperature ultraviolet nanowire nanolasers, Science, 2001, 292, 1897-1899.

5 K. Govender, D.S. Boyle, P. O'Brien, D. Binks, D. West and D. Coleman, Room temperature lasing observed from $\mathrm{ZnO}$ nanocolumns grown by aqueous solution deposition, Adv. Mater., 2002, 14, 1221-1224.

6 L. Wang, Y. Kang, X. Liu, S. Zhang, W. Huang and S. Wang, ZnO nanorod gas sensor for ethanol detection, Sens. Act. B: Chem., 2012, $162,237-243$

7 P.H. Yeh, Z. Li and Z.L. Wang, Schottky-gated probe-free ZnO nanowire biosensor, Adv. Mater., 2009, 21, 4975-4978.

8 J. Huang, Z. Yin and Q. Zheng, Applications of ZnO in organic and hybrid solar cells, Energy Environ. Sci, 2011, 4, 3861-3877.

9 B. Weintraub, Y.G. Wei and Z.L. Wang, Optical fiber/nanowire hybrid structures for efficient three-dimensional dye-sensitized solar cells, Angew. Chem. Int. Ed., 2009, 48, 8981-8985.

10 B. Chouchene, T.B. Chaabane, L. Balan, E. Girot, K. Mozet, G Medjahdi and R. Schneider, High performance Ce-doped ZnO nanorods for sunlight-driven photocatalysis, Beilstein J. Nanotechnol., 2016, 7, 1338-1349.

11 A. Osman and A. Yüksel Controlled modulation of $1 \mathrm{D} \mathrm{ZnO}$ nano/ micro structures: Evaluation of the various effects on the photocatalytic activity, J. Phys. Chem. Solids, 2017, 108, 88-97.

12 B. Baruwati, D.K. Kumar and S.V. Manorama, Hydrothermal synthesis of highly crystalline $\mathrm{ZnO}$ nanoparticles: a competitive sensor for LPG and EtOH, Sens. Act. B: Chem., 2006, 119, 676-682.

13 B. Chouchene, T.B. Chaabane, K. Mozet, E. Girot, S. Corbel, L. Balan, G. Medjahdi and R. Schneider, Porous Al-doped ZnO rods with selective adsorption properties, Appl. Surf. Sci., 2017, 40, 102-110.

14 J. Lee, A.J. Eastealb, U. Pal and D. Bhattacharyya, Evolution of ZnO nanostructures in sol-gel synthesis, Curr. Appl. Phys., 2009, 9, 792-796.

15 D. Raoufi, Synthesis and microstructural properties of $\mathrm{ZnO}$ nanoparticles prepared by precipitation method, Ren. Energy, 2013, 50, 932-937.

16 Y. Wang, C. Zhang, S. Bi and G. Luo, Preparation of ZnO nanoparticles using the direct precipitation method in a membrane dispersion micro-structured reactor, Powder Technol. 2010, 202, 130-136.

17 B. Chouchene, K. Horchani-Naifer and T.B. Chaabane, Effect of the solvent on the morphology and the size of $\mathrm{ZnO}$ nanoparticles synthesized in polyol medium, Rev. Roum. Chim., 2016, 61, 857-862.

18 A. Mezni, F. Kouki, S. Romdhane, B. Warot-Fonrose, S. Joulié, A. Mlayah and L.S. Smiri, Facile synthesis of $\mathrm{ZnO}$ nanocrystals in polyol, Mater. Lett., 2012, 86, 153-156.

19 A.M. Pourrahimi, D. Liu, L.K.H. Pallon, R.L. Andersson, A.M. Abad J.M. Lagarón, M.S. Hedenqvist, V. Ström, U.W. Geddea and R.T Olsson, Water-based synthesis and cleaning methods for high purity $\mathrm{ZnO}$ nanoparticles - comparing acetate, chloride, sulphate and nitrate zinc salt precursors, RSC Adv., 2014, 4, 35568-35577.

20 R.A. McBride, J.M. Kelly and D.E. McCormack, Growth of welldefined $\mathrm{ZnO}$ microparticles by hydroxide ion hydrolysis of zinc salts, J. Mater. Chem., 2003, 13, 1-7.

21 L. Jiang, G. Li, Q. Ji and H. Peng, Morphological control of flower-like ZnO nanostructures, Mat. Lett., 2007, 61, 1964-1967.

22 Y. Khan, S.K. Durrani, M. Mehmood, J. Ahmad, M.R. Khan and S. Firdous, Low temperature synthesis of fluorescent $\mathrm{ZnO}$ nanoparticles, Appl. Surf. Sci., 2010, 257, 1756-1761.

23 F. Demoisson, R. Piolet and F. Bernard, Hydrothermal synthesis of $\mathrm{ZnO}$ crystals from $\mathrm{Zn}(\mathrm{OH}) 2$ metastable phases at room to supercritical conditions, Cryst. Growth Des., 2014, 14, 5388-5396.

$24 \mathrm{P}$. Li, H. Liu, B. Lu and Y. Wei, Formation mechanism of $1 \mathrm{D} \mathrm{ZnO}$ nanowhiskers in aqueous solution, J. Phys. Chem. C, 2010, 114, 21132-21137.
$25 \mathrm{~J}$. Wang and L. Xiang, Formation of $\mathrm{ZnO}$ rods with varying diameters from $\varepsilon-\mathrm{Zn}(\mathrm{OH}) 2$, J. Cryst. Growth, 2014, 401, 279-284.

26 L. Guo, Y. L. Ji and H. Xu, Regularly shaped, single-crystalline ZnO nanorods with Wurtzite structure, J. Am. Chem. Soc., 2002, 124, 14864-14865.

27 J. Xie, P. Li, Y. Li, Y. Wang and Y. Wei, Morphology control of ZnO particles via aqueous solution route at low temperature, Mater. Chem. Phys., 2009, 114, 943-947.

28 A. Kołodziejczak-Radzimska and T. Jesionowski, Zinc oxide-From synthesis to application: a review, Mater., 2014, 7, 2833-2881.

29 M. Wang, Y. Zhou, Y. Zhang, S.H. Hahn and E.J. Kim, From Zn(OH)2 to $\mathrm{ZnO}$ : a study on the mechanism of phase transformation, Cryst. Eng. Comm., 2011, 13, 6024-6026.

30 W. Mao-Hua, F. Zhou and B. Zhang, Synthesis and characterization of low-dimensional $\mathrm{ZnO}$ nanocrystals in an aqueous solution, J. Alloy. Comp., 2013, 581, 308-312.

31 H.F. McMurdie, M.C. Morris, E.H. Evans, B. Paretzkin, W. Wong-Ng, L. Ettlinger and C.R. Hubbard, Standard X-ray diffraction powder patterns from the JCPDS research associateship, Powder Diffr., 1986, 1, 64-77.

32 F. Xu, P. Zhang, A. Navrotsky, Y. Zhong-Yong, R. Tie-Zhen, M. Halasa and S. Bao-Lian, Hierarchically assembled porous $\mathrm{ZnO}$ nanoparticles: synthesis, surface energy, and photocatalytic activity, Chem. Mater., 2007, 19, 5680-5686.

33 S.S. Alias, A.B. Ismail and A.A. Mohamad, Effect of $\mathrm{pH}$ on $\mathrm{ZnO}$ nanoparticle properties synthesized by sol-gel centrifugation, J. Alloy. Comp., 2010, 499, 231-237.

34 M.J. Chithra, M. Sathya and K. Pushpanathan, Effect of $\mathrm{pH}$ on crystal size and photoluminescence property of $\mathrm{ZnO}$ nanoparticles prepared by chemical precipitation method, Acta Metall. Sin. (Engl. Lett.), 2015, 28, 394-404.

35 O. Garcia-Martinez, E. Vila, J.L. Martin de Vidales, R.M. Rojas and K. Petrov, On the thermal decomposition of the zinc(II) hydroxide chlorides $\mathrm{Zn} 5(\mathrm{OH}) 8 \mathrm{Cl} 2 \cdot \mathrm{H} 2 \mathrm{O}$ and $\beta-\mathrm{Zn}(\mathrm{OH}) \mathrm{Cl}$, J. Mater. Sci., 1994, 29, 5429-5434.

36 S. Musić,Đ. Dragčević and S. Popović, Influence of synthesis route on the formation of $\mathrm{ZnO}$ particles and their morphologies, J. Alloy. Comp., 2007, 429, 242-249.

37 S.S. Kurbanov, G.N. Panin, T.W. Kim and T.W. Kang, Strong violet luminescence from $\mathrm{ZnO}$ nanocrystals grown by the low-temperature chemical solution deposition, J. Lumin., 2009, 129, 1009-1104.

38 M.K. Patra, K. Manzoor, M. Manoth, S.R. Vadera and N. Kumar, Studies of luminescence properties of $\mathrm{ZnO}$ and $\mathrm{ZnO}: \mathrm{Zn}$ nanorods prepared by solution growth technique, J. Lumin., 2008, 128, 267-272.

39 J. Yang, R.Wang, L. Yang, J. Lang and N. Yang, Tunable deep-level emission in $\mathrm{ZnO}$ nanoparticles via yttrium doping, J. Alloy. Comp., 2011, 509, 3606-3612.

40 L. Zhang, L. Yin, C. Wang, N. lun, Y. Qi and D. Xiang, Origin of visible photoluminescence of $\mathrm{ZnO}$ quantum dots: defect-dependent and size-dependent, J. Phys. Chem. C, 2010, 114, 9651-9658.

41 H.M. Xiong, D.G. Shchukin, H. Mohwald, Y. Xu and Y.Y. Xia, Sonochemical synthesis of highly luminescent zinc oxide nanoparticles doped with magnesium (II), Angew. Chem., Int. Ed., 2009, 48, 2727-2731.

42 W. Mingsong, N.K. Eun, K.S. Jae, K. J. Eui and K. Kee-Kahb, Photoluminescence of $\mathrm{ZnO}$ nanoparticles prepared by a low- temperature colloidal chemistry method, Mater. Lett., 2007, 61, 4094-4096.

43 N.R. Thimmasandra and L.M. Theeta, Thermal decomposition studies of layered metal hydroxynitrates (metal: $\mathrm{Cu}, \mathrm{Zn}, \mathrm{Cu} / \mathrm{Co}$, and $\mathrm{Zn} / \mathrm{Co}$ ), Int. J. Inorg. Chem., 2015, Article ID 536470, http://dx.doi.org/10.1155/2015/536470

44 A. Jean-Paul and L. Daniel, Etude thermodynamique de la décomposition thermique des hydroxynitrates de zinc, J. Solid State Chem., $1983,46,245-252$.

45 B. Timothy, J. William, P. Alexandra, S. Ewa and P. Jerzy, The role of anhydrous zinc nitrate in the thermal decomposition of the zinc hydroxy nitrates $\mathrm{Zn} 5(\mathrm{OH}) 8(\mathrm{NO}) 2.2 \mathrm{H} 2 \mathrm{O}$ and $\mathrm{ZnOHNO} 3 . \mathrm{H} 2 \mathrm{O}$, J. Solid State Chem., 2007, 180, 1171-1179.

46 J. Sithole, B.D. Ngom, S. Khamlich, E. Manikanadan, N. Manyala, M.L. Saboungi, D. Knoessen, R. Nemutudi and M. Maaza, Simonkolleite nano-platelets: synthesis and temperature effect on hydrogen gas sensing properties, Appl. Surf. Sci., 2012, 258, 78397843. 
